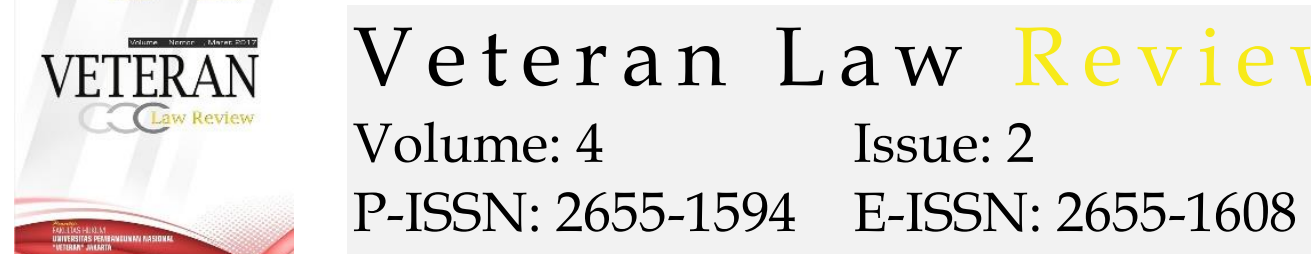

\title{
The Practice of Mbaranggawe Puputan: A Solution for Marriage Reception in Javanese Communities During the Covid - 19 Pandemic
}

\begin{abstract}
Anisatul Latifah ${ }^{1}$
${ }^{1}$ Faculty of Syari'ah and Law, Sunan Kalijaga State Islamic University, E-mail: anisatullilik@gmail.com.

\begin{tabular}{|c|c|}
\hline ARTI & ABSTRACT \\
\hline $\begin{array}{l}\text { Keywords: } \\
\text { Traditional } \\
\text { Ceremonies, Mbaranggawe } \\
\text { Pengantenan, Mbaranggaw } \\
\text { e Puputan, Covid-19. } \\
\text { How to cite: } \\
\text { Latifah, A. (2021). The } \\
\text { Practice of Mbaranggawe } \\
\text { Puputan: A Solution for } \\
\text { Marriage Reception in } \\
\text { Javanese } \\
\text { Communities During the } \\
\text { Covid - 19 Pandemic. } \\
\text { Veteran Law Review. 4(2). } \\
\text { 157-176. } \\
\text { Received: 2021-03-23 } \\
\text { Revised: 2021-04-05 } \\
\text { Accepted: 2021-10-22 }\end{array}$ & $\begin{array}{l}\text { In this paper will discuss about the practice of traditional } \\
\text { ceremonies mbaranggawe pengantenan (mantenan) and } \\
\text { mbaranggawe puputan or muputi (ceremony performed after } \\
\text { dropping the baby's navel) in javanese society especially cilacap. } \\
\text { Javanese people have a custom mbaranggawe pengantenan to } \\
\text { conduct wedding receptions. The implementation is to invite } \\
\text { invited guests from the surrounding community, from other } \\
\text { regions and from friends of both brides. The situation is very } \\
\text { crowded due to the large crowd of invited guests on the day and the } \\
\text { reception venue is often inevitable. While in the traditional ritual } \\
\text { practice of mbaranggawe puputan, it is done more simply and } \\
\text { calmly because guests come willingly on the first to seventh day of } \\
\text { the baby's birth. Guests who come are only neighbors and closest } \\
\text { friends so the crowd can be avoided. After the covid-19 outbreak } \\
\text { that damaged human health entered Indonesia, Indonesian people } \\
\text { are faced with a new normal. People are obliged to adhere to health } \\
\text { protocols, such as avoiding crowds and maintaining social distance, } \\
\text { as a prevention of the transmission of covid-19. After the covid-19 } \\
\text { outbreak, Javanese people, prefer the concept of traditional } \\
\text { ceremonial practice mbaranggawe puputan as a solution } \\
\text { mbaranggawe pengantenan because it is easier to implement health } \\
\text { protocols covid-19. }\end{array}$ \\
\hline
\end{tabular}
\end{abstract}

\section{Introduction}

Humans are perfect creatures with their intellect endowed with them. With reason, humans can improve the quality of life by thinking about how to cultivate actions to meet their needs and face bad possibilities or trials that hit. Even though humans are perfect creatures, humans are included as social creatures who still need other creatures to fulfill all their needs and feel calm in their life cycle. In order to maintain social relationships between one individual with another individual, humans instinctively will form an association called the community. This social life will form a certain pattern of habits so that life in it remains and is protected from extinction or damage. The habit pattern will always be carried out and taught from generation to generation because it is believed to be able to maintain, provide lessons, guidance and balance the life order in which the community is 
located. ${ }^{1}$ This habit pattern is called a tradition or cultural customs. If this tradition is violated, then it will result in a legal claim for the perpetrators, the tradition or custom has become the customary law of the community.

Javanese people are among those who always try to uphold the values of traditional and cultural traditions so that their life in the universe is always in harmony and harmony. ${ }^{2}$ One of the traditional traditions of the Javanese people in pursuing their life cycle in order to obtain peace of life, serenity, harmony and harmony with the universe is by performing certain ceremonies or customs. ${ }^{3}$ Examples of traditional ceremonies in Javanese society are mbaranggawe pengantenan (weddings) or walimatul 'Ursy and mbaranggawe muputi or puputan (ceremony performed after dropping the baby center). Mbaranggawe stands for sembarang digawe (whatever is used and made) for the purposes and needs of carrying out certain traditions or ceremonies. This ceremony is usually associated with a party or celebration of happiness. The implementation of this traditional ceremony requires the involvement of many relatives of sedulur (relatives) and tonggo teparo (neighbors) who own the hajat. ${ }^{4}$ The large number of activities and guests who will come to the mbarangngawe event cause it requires a lot of funds, energy and thoughts to prepare all needs.

In general, the wedding ceremony for the Javanese community is carried out in a more luxurious manner and has a longer series of activities. In addition, the mbaranggawe pengantenan also includes invited guests who are not only from the surrounding environment but also relatives and friends who come from outside the region. Invited guests in the mbaranggawe pengantenan tradition in Javanese society usually consist of two groups, namely the batir nom-noman penganten (young bride-to-be friends) and Kasepuhan guests (the general public). ${ }^{5}$ The batir nom-noman are guests specially invited by the bride and groom, while the Kasepuhan guests are guests invited by the parents of the bride and groom. In addition to invited guests during mbaranggawe, there are also guests of kepungan or slametan (a joint prayer event by saying prayers and tawasul for the owner of the celebration led by the priest so that the event runs smoothly and brings blessings to the family then ends with a meal together). ${ }^{6}$ Unlike the wedding mbaranggawe, mbaranggawe is simpler and has fewer guests. Mbaranggawe muputi only invites guests at the time of the celebration which is held at night and at the same time provides a name for the baby. Invitations are only given to men who are adults and are limited in number without bringing a

1 Eko Setiawan, "Tradisi Ruwatan Murwakala Anak Tunggal Dalam Tinjauan Sosiokultural Masyarakat Jawa," Asketik, 2.2 (2018), (pp. 129-38). <https://doi.org/10.30762/ask.v2i2.846>.

2 Darmoko Darmoko, "Ruwatan: Upacara Pembebasan Malapetaka Tinjauan Sosiokultural Masyarakat Jawa," Makara Human Behavior Studies in Asia, 6.1 (2002), (pp. 30) <https://doi.org/10.7454/mssh.v6i1.29>.

3 Indah Aswiyati, “Makna Dan Jalannya Upacara 'Puputan' Dan 'Selapanan' Dalam Adat Upacara Tradisional Kelahiran Bayi Bagi Masyarakat Jawa," Jurnal Holistik, VII.16 (2015), (pp. 1-10).

4 Anisatul, Intervew Humam, Leader of Serang Mosque (Cilacap, 2020).

5 Anisatul, Intervew Humam, Leader of Serang Mosque.

6 Koentjaraningrat, Manusia dan Kebudayaan di Indonesia.(Jakarta: Djambatan, 2004) 
donation. As for the guests who come when mbaranggawe muputi are usually only women from the surrounding neighbors, they bring some basic necessities to just give donations to the owner of the party.

The existence of changing times and technology that has developed until now is clearly very influential on human life. Demanding needs and urgent circumstances make people try hard so that their lives can stay in harmony and keep going. The factors of changing times and technology have an effect on beliefs, the trend towards a more practical outlook and mindset. ${ }^{7}$ Javanese traditional ceremonies are also affected by this change. The result of these changes has resulted in a shift in the substance or function of adat in society. Traditional ceremonies that are held in Javanese society have experienced a shift in meaning from a sacred magical belief to a symbolic one. Apart from this shift, sometimes the implementation of traditional ceremonies is held only because of social pressure which contains negative views if the adat is not carried out.

This outbreak is known as Covid-19. The beginning of the corona case was reported with symptoms of pneumonia (shortness of breath) which was associated with a fish market in Wuhan, Hubei Province, China. ${ }^{8}$ A new life order is required to be implemented as a way to prevent the spread of Covid19 in Indonesia. ${ }^{9}$ The impact of demands and changes that were very felt was highlighted because of the corona virus outbreak that emerged at the end of 2019 which attacked human health, resulting in several regulations being issued. The beginning of this regulation was intended for public places such as offices and other workplaces that were considered to be at very risk of transmitting Covid-19. The implementation of activities in public places, such as offices, schools and markets, is urged to be carried out from home (work from home) or online to carry out social distancing. The program that was promoted to avoid Covid-19 was by means of a Clean and Healthy Lifestyle (PHBS), namely the $3 \mathrm{M}$ community movement (germas); wash your hands with soap, keep your distance and wear a mask. This program is predicted as a way to prevent the transmission of Covid-19. If it is urgent to meet face-to-face, the number of participants present and the duration of the meeting is limited.

Ceremonial activities or traditional traditions carried out by the Javanese community are also affected because of this regulation. The implementation of traditional ceremonies is very strict, including the limited number of participants, time of implementation and location plans to be used in the event. With this rule, traditional ceremonial activities that are considered sacred are still carried out even though they are simple. Like mbaranggawe, the wedding is carried out as simply as mbaranggawe puputan with the aim of reducing the number of guests who may attend. If this tradition is not carried

7 Venny Indria Ekowati, "Tata Cara Dan Upacara Seputar Daur Hidup Masyarakat Jawa Dalam Serat Tatacara," Diksi, $15.2 \quad$ (2015), (pp. 204-205). <https://doi.org/10.21831/diksi.v15i2.6608>

8 Adityo Susilo et al., "Coronavirus Disease 2019: Tinjauan Literatur Terkini," Jurnal Penyakit Dalam Indonesia, 7.1 (2020), (pp. 45). <https:// doi.org/10.7454/jpdi.v7i1.415>.

9 Tribunnews, "Kemenkes RI Keluarkan Panduan Pencegahan Covid-19 diera New Normal," 2020. 
out, it will cause talk that is felt to be burdensome for the perpetrators. This talk is a sanction as a result of not obeying the customs that have been believed and carried out from generation to generation.

\section{Method}

Based on the description above, this study intends to examine the practice of mbaranggawe puputan as a solution to mbaranggawe pengantenan or walimatul 'ursy in the Javanese, especially in Serang, Javanese-Cilacapcommunity during the Covid-19 pandemic. This research includes field research, namely research whose data sources come from the field or reality. Occurs in society by emphasizing the five senses. ${ }^{10}$ The data collection method used by the researcher is by conducting interviews or interviews with the bride and groom and the parents of the bride and groom as mbaranggawe puputan actors and several neighbors who participated in the event. The data processing is qualitative analysis with analytic descriptive method. The approach used in this research is the anthropological approach.

3. The Mbaranggawe Puputan: A Solution for Marriage Reception in Javanese Communities During the Covid - 19 Pandemic

The importance of discussing this is to know what is the core function of the existence of mbaranggawe customs in Javanese society. Based on the results obtained from the function of customary practice in Javanese society, the community will better uphold the core of the function. If this function is difficult to carry out as a whole because of extraordinary circumstances such as the covid-19 pandemic then the community will tend to continue to practice customs without eliminating the essence of sacredness even with simple and limited conditions. The most important thing is to keep the customs running by taking the essence of the function of mbaranggawe customary practice.

\subsection{The Covid-19 Pandemic}

Coronavirus is a virus that is included in the virus family that causes mild to severe symptomatic diseases, such as the common cold or colds and serious diseases such as MERS and SARS. Transmission covid-19 was originally known by way of direct contact with animals or humans are exposed. When this virus was known to have hit Wuhan, the Wuhan government closed all forms of activity in the area. Even though Wuhan has been closed, the fact is that this virus continues to spread to other areas in China to other countries because this virus has not been clearly identified. Some time later, WHO announced that transmission of Covid-19 could occur through droplets from breath, sneezing, coughing from infected people and confined air in rooms that have been contaminated with the virus. ${ }^{11}$ From this new discovery by $\mathrm{WHO}$, it is very influential on human life. People who usually carry out

10 Soerjono Soekanto, Pokok-Pokok Sosiologi Hukum, (pp. 8). (Jakarta: Rajawali Grafindo Persada, 1997).

11 Covid19.go.id, "Who Sebut Penularan Corona Tak Lagi Hanya Lewat Droplet Tapi Juga Udara." 
activities that require the existence of a busy gathering are limited. The latest discovery, Covid-19 spreads through air conditioners or in closed rooms. ${ }^{12}$ Then the corona together with other microbes as a reservoir, are inhaled into the central nervous system. This can cause the central nervous system to become infected. Covid-19 can develop and infect if he is in the host. ${ }^{13}$ The form of the infection varies depending on the immune state of the host. Symptoms that will arise can be mild, moderate or severe.

Initially the name that caused this disease was 2019 Novel Coronavirus (2019nCoV). ${ }^{14}$ WHO (World Health Organization) or the world health organization then announced the new naming of this virus with the name Severe Acute Respiratory Syndrome Coronavirus- 2 (SARS-CoV-2) and the disease caused by this virus is Coronavirus Disease (Covid-19). ) on February $11,2020.15$ SARS-CoV-2 is believed to be the virus that causes pneumonia, which is worldwide today. Symptoms that are shown when a person has been exposed to this virus are the presence of fever more than $38^{\circ} \square \mathrm{C}$, cough, shortness of breath which requires strict hospitalization. These symptoms can be more severe and dangerous if the person exposed to this virus is a person who has or has chronic diseases such as the lungs and heart. The impact of the outbreak of this disease in Wuhan until January 12, 2020, is still low in mortality. There were 198 cases reported to the government, only 2 deaths occurred.

Covid-19 was first detected in Indonesia with a pickle in Jakarta which caused 2 Indonesian citizens (WNI) to come into direct contact with Japanese citizens (WNA) living in Malaysia who had suffered from Covid-19. After the meeting at the event, the patient complained of experiencing fever, coughing and shortness of breath. The number of people with Covid-19 has increased over time. The number of cases that occur in the community is due to not being careful when in public places or crowds. Covid-19 in Indonesia totaled 1528 cases and counted as many as 136 cases of death as of March 2020 and became the highest country in Southeast Asia in the number of mortality cases of Covid-19.

Formation regulations related to the prevention of Covid-19 in Indonesia are very important and urgent to do in the form of a Government Regulation and a Minister of Health Regulation for the safety of all the people. ${ }^{16}$ In response to and in anticipation of preventing the spread of Covid-19, the Indonesian health ministry issued a Circular to all Provincial and City District Health Offices, Referral Hospitals, Port Health Offices (KKP) and Environmental Health Engineering Centers (BTKL) to increase awareness

12 Ruqaiyyah Siddiqui, Mohammad Ridwane Mungroo, dan Naveed Ahmed Khan, "SARSCoV-2 invasion of the central nervous: a brief review," Hospital Practice, 00.00 (2021), (pp. 1-7). <https://doi.org/10.1080/21548331.2021.1887677>.

13 Y Yuliana, "Corona virus diseases (Covid-19): Sebuah tinjauan literatur," Wellness And Healthy Magazine, 2.1 (2020), (pp. 187-192). <https://doi.org/10.30604/well.95212020>.

14 KEMENKES, "Tentang Novel Coronavirus (NCoV),."

15 WHO, "Emergencies Diseases Novel Corona Virus-2019."

16 Dalinama Telaumbanua, "Urgensi Pembentukan Aturan Terkait Pencegahan Covid-19 di Indonesia," QALAMUNA: Jurnal Pendidikan, Sosial, dan Agama, 12.01 (2020), (pp. 59-70). $<$ https://doi.org/10.37680/qalamuna.v12i01.290>. 
and always ready to be on standby to prevent this disease from entering Indonesia. This is done by activating a thermal scanner, providing health alert cards and KIE to passengers. The broader distribution of IEC to the community aims to keep people calm and remain alert to this disease. LargeScale Social Restrictions (PSBB) and certain area closures (lockdowns ) are also often enforced in areas marked as red zones (criteria for areas with high risk of transmission).

Areas based on the risk of covid-19 transmission are divided into four areas, namely the green zone (not affected), the yellow zone (low risk), the orange zone (moderate risk) and the red zone (high risk). The characteristics of the area that becomes the red zone are the rapid spread of the corona virus between surrounding residents and the emergence of new distribution clusters (health groups). ${ }^{17}$ The restrictions imposed on the red zone in general are intensive virus testing, close contact tracking of patients who are positively infected, patients under surveillance (PDP) and people under surveillance (ODP), stay at home, are not allowed to travel. Public gatherings except for urgency (such as pharmaceuticals and staples) by always implementing health protocols, closing public facilities and prohibiting crowd-inducing activities. ${ }^{18}$ The orange zone still allows people to travel but is restricted such as maintaining strict health protocols and travel due to urgent needs such as the need for staple food and pharmaceuticals, public places are temporarily closed such as educational facilities. This limitation due to the possibility of transmission is very likely to occur. The yellow zone has a more controlled distribution cluster than the orange zone. The yellow zone allows activities and activities outside the home such as business, religious activities to be carried out normally and it is permissible to open public facilities but must comply with strict health protocols. Vulnerable groups such as parents and toddlers are advised to stay at home.

Appeals to the community were also carried out by carrying out community movements (germas) to always practice PHBS, wash hands frequently with soap, maintain contact with animals, market animals and avoid eating raw meat. Apart from avoiding direct contact with animals in exposed areas, people are also advised not to avoid direct contact with people who are sick. If there are complaints with the characteristics of Covid-19 such as shortness of breath, coughing and sneezing, it is advisable to immediately conduct an examination at the nearest health service. Using a mask in carrying out daily activities and practicing ethics when coughing or sneezing to avoid transmission to others. This call is called the health protocol. The green zone is characterized by no positive cases, the risk of spreading is very low only in isolation places and there is strict supervision to prevent potential new cases from arising. Things that are done in the green zone are to carry out strict supervision at regional entrances, cross-regional population mobility, implementation of health protocols and social religious activities are opened with the obligation to comply with health protocols

17 Detik.com, "Istilah Virus Corona dan Artinya Klaster Hingga Airborne."

18 Nasional.kontan.co.id, "Inilah Pembagian Zona Wilayah Penyebaran Corona Berdasarkan Risiko." 
(especially the obligation to stay at home for people who are sick even though they are mildly ill like the flu and cough).

The increasing number of Covid-19 cases in Indonesia is largely influenced by the fact that the public has not complied with the health protocol regulations from the government and the low level of public awareness in responding to Covid-19. People still often carry out activities outside the home without wearing masks. Avoiding crowds or carrying out activities of a mass nature are also often done without heeding health protocols. Like the case of the crowd at Soekarno Hatta airport during the return of Habib Rizieq Shihab (HRS), which had previously been announced regarding his return to Indonesia from Saudi Arabia with a video that was circulated in cyberspace. ${ }^{19}$ The spread of video on the return HRS rated as the cause of a crowd of masses at Soekarno Hatta airport. In addition, the crowd of mass also occurred in Petamburan, Central Jakarta at the time of his daughter marrying HRS conjunction with Prophet Muhammad's birthday celebration activities. The background of this crowd was due to an element of invitation by HRS to the congregation to come to the event through videos circulating on social media. HRS was charged with the article of incitement for violating the health protocol which at that time the PSBB (Large-Scale Social Restriction) was in effect in the Jakarta area. Apart from these cases, there are also cases that endanger the health of others because they do not comply with the health protocol rules in the form of PSBB by a cafe in Jakarta. The cafe manager is subject to sanctions by being temporarily closed for $1 \times 24$ hours. $^{20}$ Transmission from hospitalized patients to medical personnel has also contributed to increasing the transmission rate in Indonesia. People who are elderly and who have chronic diseases such as cancer and detected liver disease are more susceptible to infection with SARS-COV-2.

In addition to affecting health and affecting the community's economy, the Covid-19 pandemic has also greatly affected the way of life and social life in society. Activities that continue to involve large crowds of people are likely to increase transmission because it is very difficult to know who has been exposed to the virus. Distance between individuals in a crowd is very difficult to do. Examples of activities that are restricted and even their implementation must be avoided are work in offices, religious activities, teaching-learning activities and traditional ritual activities that involve many individuals or communities. Even though the people are not infected, an area will still be affected by Covid-19 from an economic point of view, for example. There are reports that say that countries that are not infected with this virus have decreased their sources of income from the tourism sector so that the people's economy has experienced a decline. These countries are Palau, Micronesia, Marshall Islands, Nauru, Kiribati, Solomon Islands, Tuvalu, Samoa, Vanuatu and Tonga. ${ }^{21}$

19 Cnnindonesia.com, "Kasus Kerumunan dan Jerat Pasal Penghasutan Untuk Rizieq."

20 Kompas.com, "Kilas Balik Penertiban Kerumunan Massa di Tengah Pandemi Kafe Disegel."

21 Bbc.com, "indonesia dunia." 


\subsection{Mbaranggawe Puputan}

The cycle in human life according to the tradition of Javanese society is a tradition that is carried out because of the process of moving the stage (rites of passage ) from the beginning of birth, everyday life, to the stage towards adulthood which is considered more difficult, the problem then drops sloping with death. ${ }^{22}$ The phases of human life according to Javanese society can be grouped into several events resulting in different rituals in each cycle and phase, namely: ${ }^{23}$

a. Birth cycle.

In this cycle there are different types of rituals. Among other things, ngupati / ngapati (carried out when a person's pregnancy reaches 120 days or about 4 months of gestation), nglimoni (carried out when the first gestational age reaches 5 months of age), mitoni or also called tingkeban (done when gestational age reaches 7 months), nyangani (done when the gestational age reaches 9 months of age), brokohan (done on the day of the baby's birth or so-called salvation for the baby's birth), sepasaran (congratulations done on the 5th day of the birth of the baby as well as giving the baby's name. There are also those who carry out feast and bancakan), puputan (carried out when the remaining umbilical cord is loose, usually Javanese people call it pupak), selapanan (carried out on the 35th day of the baby's birth), tedhak siti (carried out when the age of the child reaches 7 eight or about 245 days with prayer climbing rituals so that children become honest children, worship experts, science experts, generous and have a high work ethic), year after year (carried out $s$ when the child reaches 1 year old).

b. Mating cycle

In this cycle there are five rituals, namely kumbakarnan (carried out 7 days before the wedding day as a form of gratitude after preparatory deliberations related to the wedding ceremony), tarub pairs (carried out 2 or 1 day before the wedding day), midadareni and majemu (carried out on the night before the wedding. done as a symbol of the kembar mayang ransom (The Kembar Mayang ransom is carried out by means of the prospective groom "nyantri" at the house of the future wife as a traditional wujut inherited from the Prophet Musa studying and staying for one night at the house of the Prophet Syu'aib on the night of the wedding ceremony) and after that a gathering is held by praying for the safety of all the series of events that will be carried out), walimahan (carried out after the consent qabul or marriage ceremony) and sepasaran manten (held on the 5th day of the qabul agreement).

22 Titiek Suliyati, "Upacara Tradisi Masa Kehamilan dalam Masyarakat Jawa," ejournal undip.

23 Muhammad Sholikhin, Ritual Dan Tradisi Islam Jawa; Ritual-Ritual Dan Tradisi Tentang Kehamilan, Kelahiran, Pernikahan, Dan Kematian Dalam Kehidupan Sehari-Hari Masyarakat Islam Jawa, 1 ed. (Yogyakarta: Narasi, 2010). 
c. Death cycle

In this cycle, a ritual is carried out as a request from the heirs of the deceased so that the deceased person gets good before God Almighty. This ritual is surtanah (performed after the corpse is buried so that the spirit has a noble place in God's side), nelung dina (carried out on the 3rd day after the corpse dies by praying for the corpse to forgive its sins and get a clear path to God), mitung dina (carried out on the 7 th day after the death of the corpse by praying and as a symbol of perfecting the skin, hair and nails of the corpse), tens of maturity (carried out on the 40th day from the day of the death of the corpse by praying that the corpse will get a noble place according to his good deeds and incarnate al-Quran), nyatus dina (carried out on the 100th day of the day of death with the aim of praying for salvation to the corpse and as a symbol of the completion of the corpse), mendhak pisan (done in the first year of death which is usually calculated by counting the hijriyyah date by praying for the corpse on physical factors other than bones), mendhak pindho (performed in the second year of the camp atian whose purpose is the same as mendhak pisan and as a symbol of taste and smell elements disappearing), nyewu dina (carried out on the 1000th day of the day of death) and haul or kol (carried out annually on the day and month when the corpse dies with the aim of praying for goodness to the corpse).

Mbaranggawe puputan is included in the ritual in the early phase of the human life cycle according to Javanese society. This event is carried out after puput (break) of the baby's umbilical cord. Implementation (5 days after the birth of the baby). In the Java community, especially in the area of Cilacap, tradition sepasaran and puputan done simultaneously as distance adjacent to its implementation. In addition, the puput of the baby's umbilical cord does not always occur 5 days after the birth of the baby, sometimes even longer. This merger is considered to be more efficient in the use of energy, time and funds spent. The essence of the combined implementation of this tradition is the same, namely to be grateful for God's gifts given to the family or the parents of the baby. ${ }^{24}$ The Javanese community called a thanksgiving ceremony or slametan by praying together and giving alms to neighbors and invited guests in the form of a banquet.

Unlike the special banquet during the mbaranggawe puputan event, a simple meal is also prepared after the baby is born until the puputan is performed. The activity of visiting babies and mothers after giving birth is called muyi (short for metu Bayi or coming out of a baby). ${ }^{25}$ Guests arrive with more flexible durations and to minimize crowds. Guests who come usually include cangkingan krendeng to bring only durable or long-lasting staples such as rice, noodles, oil and just pacitan or kriyikan (a kind of dry snack) as a contribution to the neighbor's solidarity. If you do not bring krendeng cangkingan, guests will replace them with petukon jamu which was handed

24 Anisatul, Intervew Humam, Leader of Serang Mosque.

25 Anisatul, Intervew Pairin, Leader of village, 2020. 
over to the mother of the baby. petukon jamu is money wrapped in envelopes given by guests directly to the mother or father of the baby by saying "kanggo tuku jamu" as courtesy. Kanggo tuku jamu means to buy herbal medicine because babies in Javanese society are synonymous with a high need for herbs.Guests will continue to arrive until puputan time, on which day the guests come in larger numbers. Even so, the guests who come are usually only from the local community or neighbors. If there are guests from other areas, it is usually only the family or the closest person to the baby's family and is representative only.

Puputan ceremonial equipment has a specific meaning and purpose. The equipment is:

a. Sekul Gudangan, which is rice with side dishes of vegetables seasoned with grated coconut. Makananya is that the baby is expected to be healthy fresh fit. Apart from secul warehouses, Javanese people also use tumpeng in this event. Tumpeng is an acronym for tumapaking penguripan-tumundak lempuju pangeran (oriented to the thought that humans must live in the way of Allah). ${ }^{26}$

b. Jenang Abang-putih and baro-baro, which symbolizes the hope of giving forgiveness from parents to children's mistakes, giving prayers of parents' blessings to children and respecting the amniotic fluid and placenta which are considered as baby siblings because they have accompanied the baby in the womb until the baby is born.

c. Jajanan pasar, namely various snacks purchased from the market as a symbol of glory or wealth.

d. Blukangan, namely toys made of paper (in the form of umbrellas and banners) and bamboo (in the form of kris and spears) which are stuck on the debog (banana tree trunk) and then placed near the baby's bed. This blukang means to attract the attention of evil spirits who will disturb the baby so that the baby is safe from the disturbance.

e. Gandhik or a tool for pounding herbs. This Gandhik is drawn like a baby shape which is then wrapped in paper and then placed on top of the new nyiru (tampah) covered with senthe leaves (taro leaves) then placed near the baby's bed. The meaning of this Gandhik is also as a trick for evil spirits so as not to disturb the baby.

f. Sawuran namely jejamuan that terdidi of onion, dlingo, bengle entered in to kupat brick or kupat outside as a symbolngluwari janji (pay off debts, promises or nadzar).

g. Tumbuk Suwuk, which is a broom stick that has been used before, then put it upside down by sticking an empon-empon (herbs) at the end of the broom stick as a weapon to prevent evil spirits from disturbing the baby.

26 Murdijati Gardjito dan Lilly T. Erwin, Serba-Serbi Tumpeng; Tumpeng Dalam Kehidupan Masyarakat Jawa (Jakarta: PT gramedia Pustaka Utama, 2010). 
h. Lawa Wenang is a thread that runs in every corner of the room or nursery which is used as a barrier against evil spirits from entering the nursery.

i. Kemarung leaves and thorny leaves attached to the corners of the house and streaks of welang (made with stove angus and whiting) are placed in front of the door of the house. This equipment means a form of rejection of all disturbances from outside the house so that they cannot enter through every corner and door of the house.

j. Kuwali or pitcher symbolizes the world and teplok or damar (lamp) symbolizes the light that illuminates the darkness of the world.

k. Bracelet of thread strung with slices dlingo, bengle used as a barrier evil spirit that will irritate the baby.

The series of events from the puputan is simpler and more flexible. Beginning with the whistle cord of the baby and then around the house or the baby's room is lined with a cross beam treatment, then at every four corners of the walls of the nursery paired leaves thorny and kupat luwar that inside has been filled with sawuran while at the front door of the house fitted the image streaked Welang. The placed near the crib is mashed suwuk and nyiru upon existing gandhik with leaf pedestal Senthe sometimes added also uniformity (sharps) such as scissors or a knife. The food in the form of tumpeng and other market snacks is prepared to be served to visiting guests and invited guests during slametan at night after puputan .

At night the puputan, a slametan or feast is held, attended by invited guests from nearby neighbors and the baby's family. This slametan is usually followed by a haircut and naming ceremony. ${ }^{27}$ In Javanese families it is not uncommon for parents to name their children after the names of wayang characters whose characters are idolized. The names of these figures are Yudhistira, Bima, Arjuna, Sadewa, Gatotkaca and Kresna. This is intended so that the child has the same character and policies as the character of the puppet characters. Because names are part of the prayers or hopes of the parents for their children, it is very rare that even Javanese parents name their children with evil figures such as Duryudana, Durna, Sengkuni, Dasamuka, and Sarpakenaka. ${ }^{28}$ If the name given does not match the person who has it, such as being sickly, having a naughty nature and often facing difficult and catastrophic problems, the Javanese people will change the name of their child. ${ }^{29}$

The series of programs is to read prayers and tawasul led by a priest. Apart from prayer and tawasul, another part of this event is the reading of the srakalan ( recitation of the prayer when the prophet Muhammad was born) by holding a baby and then cutting the baby's hair by several people who have been appointed. After the baby has his hair cut, the next program is to

27 Anisatul, Intervew Humam, Leader of Serang Mosque.

28 Burhan Nurgiyantoro, "Wayang dan Pengembangan Karakter Bangsa," Jurnal Pendidikan Karakter, 1.1 (2011), (pp. 18-34).

29 Abdur Rosid Abdul Haris, "Kabotan Jeneng; Mitos Merubah Nama Di Masyarakat Jember," http://digilib.iain-jember.ac.id/, 2018, (pp. 1-74). 
read the closing prayer and eat together. After that, the invited guests say goodbye to go home with the brekat that has been prepared from the baby's family. Brekat is a food prepared by the owner of the party as alms for invited guests in a slametan which contains rice, vegetables, side dishes and some crackers. It is called brekat because giving the food is able to bring blessings to the owner of the desire. ${ }^{30}$

After the Covid-19 that hit Indonesia and became a pandemic in the world, the implementation of mbaranggawe puputan was still carried out with strict health protocols. The government urges that all kinds of activities that invite crowds are limited and even temporarily prohibited from being carried out. ${ }^{31}$ Such as religious activities, education, and other activities such as community activities, their important activities are very limited. Guests come using masks and reduce direct contact with people who are sick even though they have minor illnesses such as coughs and flu. In addition to using masks and maintaining direct contact with sick people or people from outside the area, invited guests are also asked to wash their hands with the soap provided. The whole series of mbaranggawe puputan is attended by only a limited number of tonggo teparo. Tonggo Teparo, in Cilacap Javanese people have very minimal contact with people who come from outside the region.

\subsection{Mbaranggawe Pengantenan}

Mbaranggawe pengantenan ceremony or reception is a very long process and time. To facilitate understanding and focus of discussion in this paper, the author explains about the practice of the main event of the mbaranggawe pengantenan. The time associated with the date or day of the wedding ceremony is strongly influenced by the Javanese people's belief in the existence of good days and bad days. Javanese people believe that there are 3 months in 12 months of Java is a month that is not good for doing mbaranggawe or celebration. The three months are the month of fasting, Shawwal and Sura. ${ }^{32}$ Meanwhile, the big months, rajab and ruwah are good months for performing mbaranggawe. Besides being used to determine a good day carry pengantenan, calculation date and day of the pengantenan also be used for good and happiness for the bride and her family. If the count falls in one of the three bad months then the other month is good for the bride. If the calculation falls in a good month, the bride and groom will still be carried out or replaced with another time based on the circumstances and agreement of the parties.

The wedding tradition is very important and has sacred value in its implementation. The tradition of the bride is carried out on the day of the implementation of the marriage consent agreement. The wedding process is sacred because it is believed to be a status transfer ceremony that is not only personal, but also a family, ethnic, community and caste affair of a

30 Anisatul, Intervew Humam, Leader of Serang Mosque.

31 Shofiatul Jannah, "Penundaan Perkawinan Ditengah Wabah Covid-19," Jurnal Ilmiah Ahwal Syakhshiyyah (JAS), 2.1 (2020), 41 <https://doi.org/10.33474/jas.v2i1.6840>.

32 Atiek Walidaini Oktiasasi, "Perhitungan Hari Baik Dalam Pernikahan (Studi Fenomenologi Pada Keluarga Muhammadiyah Pedesaan Di Kecamatan Kertosono Kabupaten Nganjuk)," Paradigma, 4.3 (2016), (pp. 1-10). 
group. ${ }^{33}$ Mbaranggawe bride requires a lot of manpower, funds and a lot of time to run smoothly. The owner of Hjat will ask for help from Tonggo Teparo to be willing to help with the event such as distributing ulemulem or nyorogi (spreadinginvitations), masang tratag (installing tarub tents), cooking and ngladeni (welcoming and serving) guests. The bigger the event, the bigger and the more energy, funds and time needed.

Implementation ulem - ulem or nyorogi done about 6 to 4 days before the day of the event. Invited guests in the mbaranggawe wedding tradition in Javanese society usually consist of two groups, namely the nom-noman batir bride (young bride -to-be friends) and Kasepuhan guests (the general public). If the address of the person to be given ulem-ulem has a long distance, the owner of the party will send a man who knows the area or address. Whereas in the areas where the people live, the spread of ulem-ulem or sorogan is usually carried out by women. The existence of ulem-ulem or sorogan is a form of invitation to attend the wedding ceremony. The next preparation is putting up tarub or tents. This activity is usually carried out by men either from the tenant (if the tent is rented) or the neighbors (if the tent belongs to the community group). The cooking and cooking program is carried out since the ulem-ulem activity is carried out until one day after the wedding is carried out.

On the night of towong or the night before the morning of the implementation of the mbaranggawe, the wedding is usually carried out by kepungan, which is attended by male invited guests from Tonggo Teparo and their relatives. This activity is not much different from the Javanese slametan program in general, namely the process of reciting prayers and prayers carried out in congregation led by an imam or a village community leader. The purpose of the event kepungan of this is to mememohonkan that mbaranggawe running smoothly and marriages performed by the bride and groom can be lasting and happy marriage. This kepungan event ends with a meal together then the guests will say goodbye afterwards bringing the blessings that have been prepared.

On the morning of the implementation of the mbaranggawe for the wedding, the whole family and the tonggo teparo carry out the task that has been entrusted by the owner of the hajat to prepare food dishes and pacitan (snacks) for invited guests who are present. The implementation of the Kabul consent is carried out at the Office of Religious Affairs or at the place where the wedding mbaranggawe is held. If the Kabul consent is carried out at the mbaranggawe place, it is usually done in the morning around 08:00 to $12: 00$ so the invited guests who come early will witness it. After the consent granted, invited guests are welcome to enjoy the dishes that have been available. Invited guests will come and go from morning to night. In general, guests who come from morning to evening are Kasepuhan guests and female guests from neighborhoods who have hajat. Meanwhile, at night, guests who come are male Kasepuhan guests and nom - noman guests .

33 Yulia, Buku Ajar Hukum Adat, 1 ed. (Unimal Press, 2016). 
Invited guests come with cangkingan krendeng which will be affixed with the name and address of the guest who brings it as an identity in the guest book before being handed over to the owner of the hajat. This guest book is useful as guest attendance data and what they bring. This note is very important because it is used as a benchmark for returning what the guest gives to the owner of the party when the owner of the party becomes an invited guest in the guest mbaranggawe. Although this cankingan krendeng is a form of contribution from invited guests to the owner of the hajat, the return is considered a debt. Krendeng Cangkingan is usually brought by Kasepuhan female guests and female guests who come from the tonggo teparo arround the people that have hajat. Guests who come from distant areas generally prefer ngamplopi (ngamplopi is to give donations in the form of money by guests at the mbaranggawe custom which is put in an envelope to the owner of the party.) because it is considered lighter and less complicated. Ngamplopi also commonly performed by a kasepuhan male and nom - noman by affixing the name and address of the guest. The purpose of writing the name and address of the guest is to make it easier to record the guest book. Ngamplopi is also included in the form of donations from guests to the owner of the hajat but the return (punished) becomes a payable. If the current owner of the party makes a donation that is different from the amount or value of the donation that has been given by the guest, it will cause uncomfortable talk and social relations for the two of them. ${ }^{34}$

After the existence of Covid-19, the implementation of the custom of the mbaranggawe bride was simple and limited. Each series of events that have been arranged is only attended by certain invited guests and local residents or tonggo teparo where the owner lives. Invitations are usually done to spread ulem-ulem or nyorog, after Covid-19, an invitation made orally directly from the bride to the invitation nom-noman who live around the area. The friend who came from outside the region, notifications and requests prayer blessing is done through social media and does not include an invitation to attend the event pengantenan. ${ }^{35}$ Even though there was an announcement from friends who were outside the region, I felt reluctant because I did not invite them to come to this event. ${ }^{36}$

\subsection{The Practice of Mbaranggawe Puputan: A Solution for Marriage} Reception in the Cilacap Javanese Community during the Covid Pandemic 19 Viewed by Bronislaw Malinowski's Functionalism Theory in Anthropology

Bronislaw Malinowski (1884-1942) was an Austrian anthropologist born in Crascow in $1884 .{ }^{37}$ Bronislaw draws on the theory of functionalism from research in Australia during the First World War. This theory is very important in exploring custom or culture and what is the function and

4 Anisatul, Intervew Pairin, Leader of village.

Anisatul, Interview Fitri Khoerunnisa, 2020.

Anisatul, Interview Eka Sari, 2020.

37 Moh Soehadha, "Bronislaw Malinowski: Teori Fungsionalisme Dalam Studi Agama," Religi Jurnal Studi Agama-Agama, IV.1 (2005). 
meaning in every process and equipment of custom or culture in the field. Like Brownislaw's research, this Austrian scientist found very important research results and became a useful theory as a reference for anthropological research afterwards.

Strictly and briefly, the theory presented by Bronislaw Malinowski is as follows: ${ }^{38}$

All human activities or activities in cultural elements are parts that are useful for the society in which he lives, every pattern of behavior has meaning and everything in culture is intended to satisfy a series of a number of human needs.

The concept is formulated into several levels of abstraction of cultural aspects:

a. Automatically interrelationship, influence and effect on other aspects.

b. Concept by the community concerned.

c. Elements in the social life of a functionally integrated society.

d. The essence or essence of these activities is none other than to serve to fulfill the basic needs of human "biological".

According to description above, when viewed from the theory of functionalism carried by Malinowski then it can be described what the meaning of a custom implementation mbaranggawe pengantenan and bellows and the reasons that lie behind the current pandemic Covid-19.

a. All concepts of cultural customs that exist in society are elements of life that are interconnected with each other such as the interrelationship of safety and tranquility of inner birth in the social life of the community. If one does and obeys the existing customs, then the home life will feel more safe and comfortable.

b. The implementation of the custom mbaranggawe bride has a concept like mbaranggawe puputan still has sacred value even though it is done simply. All the most important series of events are carried out even with the minimalist-formality concept. The series that is considered important and sacred is the procession of consent given marriage and slametan as an effort to pray for goodness and blessings for the family and the bride.

(If you are going to do mbaranggawe during a Covid-19 situation like this, the important thing is that the consent granted to marriage and slametan is still carried out. The most important element is the marriage, while salvation is the second element after the marriage is carried out. Slametan is a form of effort from my servant to his task to give consent and blessing, prayers and wishes) $)^{39}$

1. The implementation of the mbaranggawe wedding tradition is conceptualized like mbaranggawe puputan, which protects more from social sanctions. The custom of the mbaranggawe wedding is still carried

38 Unnes.ac.id, "Teori Fungsionalisme Malinowski."

39 Anisatul, Intervew Humam, Leader of Serang Mosque. 
out even though the number of invited guests and rewangan (tonggo teparo who are asked to help in the event) is smaller, as in the slametan puputan event. The implementation of this custom provides an opportunity for the tonggo teparo and their relatives to give back the donation debt in the form of cangkingan krendeng and ngamplopi that the owner has given a wish to give so that he does not become the object of Tonggo Teparo's talk.

(People who do not practice the mbaranggawe custom will clearly receive a talk. It is considered that they do not want to protect the culture and do not want to give donations to others. It is different if you do not carry out mbaranggawe because the area here is in the red zone, the people will surely understand. $)^{40}$

2. Custom implementation mbaranggawe pengantenan conceptualized as mbaranggawe bellows more awake than transmission Covid-19. The implementation of mbaranggawe wedding customs such as simpler mbaranggawe puputan and avoiding crowds is one form of awareness in carrying out health protocols. In addition to overcoming the transmission of Covid-19 in the Javanese Serang Cipari Cilacap community, the community also maintains the preservation of Javanese cultural customs which have noble and sacred values. This means that, the existing tradition is done as the basis of maintaining the needs of the biological core, namely keeping human life in existence and maintained.

All customary practices that exist in javanese people's lives have certain ordinances. Carrying out the custom is a form of obedience and appreciation to the custom, while abandoning the custom includes a despicable and deserving act to get sanctions. Sanctions are a form of ransom for the social life balance that is violated. Sanctions obtained by someone who violates the minimum is in the form of scorn from indigenous peoples. If a situation is urgent and it is not possible to carry out certain cultural customs or traditions, then the offer of solutions will appear in order to maintain the balance of people's lives and avoid social sanctions that confront. These urgent circumstances can be natural disasters, plagues and life-threatening circumstances such as death. this explanation is like the traditional ceremonial practice of mbaranggawe puputan as a solution mbaranggawe pengantenan during the pandemic covid-19. The practice of mbaranggawe pengantenan ceremony will be difficult to implement normally and perfectly because of the pandemic covid-19 that threatens human life. Therefore, the practice of mbaranggawe pengantenan is carried out like a simpler mbaranggawe puputan to be protected from the spread of covid-19. Although carried out simply but the essence of the practice of this ceremony is not lost, namely maintaining the sacredness of the ceremony, maintaining the balance of social life of the community, maintaining the preservation of customs and protecting life as the basis of human needs.

40 Anisatul, Interview Tijan Hanafi, 2020. 


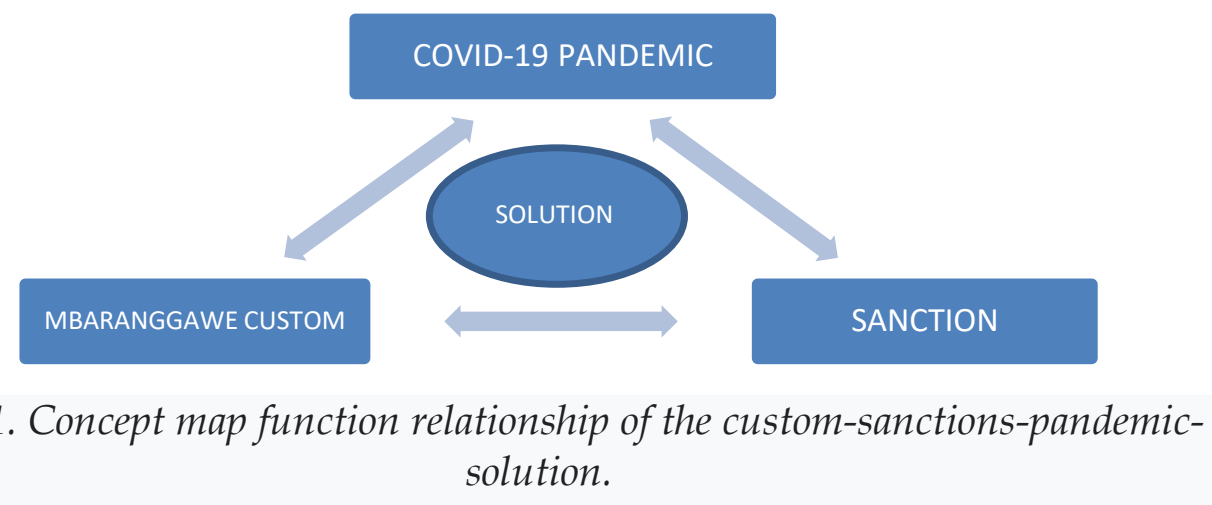

Image 1. Concept map function relationship of the custom-sanctions-pandemicsolution.

\section{Conclusion}

The implementation of the mbaranggawe pengantenan tradition is conceptualized as mbaranggawe puputan is:

a) All concepts of cultural customs that exist in society are elements of life that are interconnected with each other such as the interrelationship of safety and tranquility of inner birth in the social life of the community.

b) A transformation still has sacred value in human life and is a form of a servant's effort to his Lord so that his life is better, happier and filled with blessings.

c) A transformation of customary implementation without leaving the function of the custom, namely the function of customary existence. As a solution offer in order to maintain the balance of people's lives and avoid social sanctions.

d) The fulfillment of human biological needs. This The next function of transformation is to maintain a more peaceful community life in a sociocultural environment and to protect it from the damage caused by Covid-19.

\section{References}

\section{Books}

Koentjaraningrat, (2004), Manusia dan Kebudayaan di Indonesia Jakarta: Djambatan.

Murdijati Gardjito dan Lilly T. Erwin, (2010), Serba-Serbi Tumpeng; Tumpeng Dalam Kehidupan Masyarakat Jawa Jakarta: PT gramedia Pustaka Utama.

Sholikhin, Muhammad, (2010), Ritual Dan Tradisi Islam Jawa; Ritual-Ritual Dan Tradisi Tentang Kehamilan, Kelahiran, Pernikahan, Dan Kematian Dalam Kehidupan Sehari-Hari Masyarakat Islam Jawa, 1 ed. Yogyakarta: Narasi.

Soerjono Soekanto, (1997), Pokok-Pokok Sosiologi Hukum, 8 ed, Jakarta: Rajawali Grafindo Persada.

Yulia, (2016), Buku Ajar Hukum Adat, 1 ed, ttt, Unimal Press.

\section{Articles}

Abdul Haris, Abdur Rosid, "Kabotan Jeneng; Mitos Merubah Nama Di 
Masyarakat Jember," http://digilib.iain-jember.ac.id/, 2018, from: http://digilib.iainjember.ac.id/307/1/LAPORAN\%20PENELITIAN.pdf

Aswiyati, Indah, “Makna Dan Jalannya Upacara 'Puputan' Dan 'Selapanan' Dalam Adat Upacara Tradisional Kelahiran Bayi Bagi Masyarakat Jawa," Jurnal Holistik, VII.16 (2015)

Darmoko, Darmoko, “Ruwatan: Upacara Pembebasan Malapetaka Tinjauan Sosiokultural Masyarakat Jawa," Makara Human Behavior Studies in Asia, 6.1 (2002), 30 https://doi.org/10.7454/mssh.v6i1.29

Ekowati, Venny Indria, "Tata Cara Dan Upacara Seputar Daur Hidup Masyarakat Jawa Dalam Serat Tatacara," Diksi, 15.2 (2015), https://doi.org/10.21831/diksi.v15i2.6608

Jannah, Shofiatul, "Penundaan Perkawinan Ditengah Wabah Covid-19," Jurnal Ilmiah Ahwal Syakhshiyyah (JAS), 2.1 (2020), https://doi.org/10.33474/jas.v2i1.6840

Nurgiyantoro, Burhan, “Wayang dan Pengembangan Karakter Bangsa," Jurnal Pendidikan Karakter, 1.1 (2011)

Setiawan, Eko, “Tradisi Ruwatan Murwakala Anak Tunggal Dalam Tinjauan Sosiokultural Masyarakat Jawa," Asketik, 2.2 (2018), https://doi.org/10.30762/ask.v2i2.846

Siddiqui, Ruqaiyyah, Mohammad Ridwane Mungroo, dan Naveed Ahmed Khan, "SARS-CoV-2 invasion of the central nervous: a brief review," Hospital Practice, 00.00

(2021),

https://doi.org/10.1080/21548331.2021.1887677

Soehadha, Moh, "Bronislaw Malinowski: Teori Fungsionalisme Dalam Studi Agama," Religi Jurnal Studi Agama-Agama, IV.1 (2005)

Susilo, Adityo, Cleopas Martin Rumende, Ceva Wicaksono Pitoyo, Widayat Djoko Santoso, Mira Yulianti, Herikurniawan Herikurniawan, et al., “Coronavirus Disease 2019: Tinjauan Literatur Terkini," Jurnal Penyakit Dalam Indonesia, 7.1 (2020), https:// doi.org/10.7454/jpdi.v7i1.415

Telaumbanua, Dalinama, “Urgensi Pembentukan Aturan Terkait Pencegahan Covid-19 di Indonesia," QALAMUNA: Jurnal Pendidikan, Sosial, dan Agama, 12.01 (2020), https://doi.org/10.37680/qalamuna.v12i01.290

Titiek Suliyati, “Upacara Tradisi Masa Kehamilan dalam Masyarakat Jawa,” ejournal undip, from: https:/ / ejournal.indip.ac.id/index.php/sabda/article/download/13267 $\angle 10052$.

Walidaini Oktiasasi, Atiek, "Perhitungan Hari Baik Dalam Pernikahan (Studi Fenomenologi Pada Keluarga Muhammadiyah Pedesaan Di Kecamatan Kertosono Kabupaten Nganjuk)," Paradigma, 4.3 (2016)

Yuliana, Y, “Corona virus diseases (Covid-19): Sebuah tinjauan literatur," Wellness And Healthy Magazine, 2.1 (2020), https://doi.org/10.30604/well.95212020 
Internet

Bbc.com, "indonesia dunia" from: https://www.bbc.com/indonesia/dunia$\underline{53886004}$.

Cnnindonesia.com, "Kasus Kerumunan dan Jerat Pasal Penghasutan Untuk "Rizieq from: https://m.cnnindonesia.com/nasional/2020121108464612-580785/kasus-kerumunan-dan-jerat-pasal-penghasutan-untuk-rizieq.

Covid19.go.id, "Who Sebut Penularan Corona Tak Lagi Hanya Lewat Droplet "Tapi Juga Udara from: https:/ / covid19.go.id/p/hoax-buster/salah-whosebut-penularan-corona-tak-lagi-hanya-lewat-droplet-tapi-juga-udara.

Detik.com, "Istilah Virus Corona dan Artinya Klaster Hingga Airborne" from: https:/ / health.detik.com/berita-detikhealth/d-5087972/4-istilah-viruscorona-dan-artinya-klaster-hingga-airborne.

KEMENKES, “Tentang Novel Coronavirus (NCoV)," from: https://www.kemenkes.go.id/reseurces/download/infoterkini/COVID-19/TENTANG\%20NOVEL\%20CORONAVIRUS.pdf

Kompas.com, “Kilas Balik Penertiban Kerumunan Massa di Tengah Pandemi Kafe Disegel" from: https://amp.kompas.com/megapolitan/read/2020/11/17/11534621/ki las-balik-penertiban-kerumunan-massa-di-tengah-pandemi-kafe-disegel.

Nasional.kontan.co.id, “Inilah Pembagian Zona Wilayah Penyebaran Corona "Berdasarkan Risiko from: https://nasional.kontan.co.id/news/inilahpembagian-zona-wilayah-penyebaran-corona-berdasarkanrisiko?page=2.

Tribunnews, "Kemenkes RI Keluarkan Panduan Pencegahan Covid-19 diera New Normal," 2020 from: https://jogja.tribunnews.com/2020/05/25/kemenkes-ri-keluarkanpanduan-pencegahan-covid-19-di-era-new-normal.

Unnes.ac.id, "Teori Fungsionalisme Malinowski" from: http://blog.unnes.ac.id/prestia/2015/12/03/teori-fungsionalismemalinowski.

WHO, "Emergencies Diseases Novel Corona Virus-2019" from: http://www.who.int/emergencies/diseases/novel-coronavirus2019/technical-guidance/naming-the-coronavirus-diseas-(covid-2019)and-the-virus-that-causes-it.

\section{Q\&A}

Anisatul, Intervew Humam, Leader of Serang Mosque, Cilacap, 2020

- - - Intervew Pairin, Leader of village, Cilacap, 2020

- - - , Interview Eka Sari, Bride during Pandemic Covid-19, Cilacap, 2020

- - -, Interview Fitri Khoerunnisa, Bride during Pandemic Covid-19, Cilacap, 2020 
- - - Interview Tijan Hanafi, Parents of brides during covid 19, Cilacap, 2020 